\title{
DESIGN AND IMPLEMENTATION OF A CO2 FLOOD UTILIZING ADVANCED RESERVOIR CHARACTERIZATION AND HORIZONTAL INJECTION WELLS IN A SHALLOW SHELF CARBONATE APPROACHING WATERFLOOD DEPLETION
}

Cooperative Agreement Number:

Contractor Name and Address:

Date of Report:

Award Date:

Anticipated Completion Date:

Government Award for 1996 Fiscal Year:

Project Director:

DOE Project Officer:

Reporting Period:
DE-FC22-94BC14991

Phillips Petroleum Company 4001 Penbrook Street

Odessa, Texas 79762

April 19, 1996

June 3, 1994

January 2, 2001

$\$ 2,659,515$

John S. Chimahusky

Jerry F. Casteel

January 1, 1996 - March 31, 1996

\section{DISCLAIMER}

This report was prepared as an account of work sponsored by an agency of the United States Government. Neither the United States Government nor any agency thereof, nor any of their employees, makes any warranty, express or implied, or assumes any legal liability or responsibility for the accuracy, completeness, or usefulness of any information, apparatus, product, or process disclosed, or represents that its use would not infringe privately owned rights. Reference herein to any specific commercial product, process, or service by trade name, trademark, manufacturer, or otherwise does not necessarily constitute or imply its endorsement, recommendation, or favoring by the United States Government or any agency thereof. The views and opinions of authors expressed herein do not necessarily state or reflect those of the United States Government or any agency thereof.

\section{MASTER}

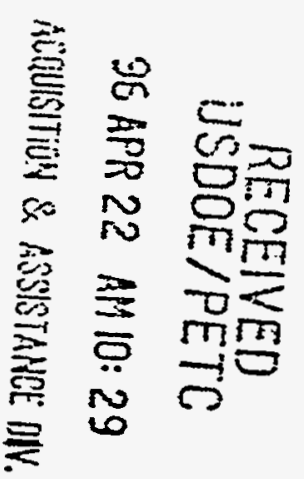




\section{OBJECTIVE}

The first objective is to utilize reservoir characterization and advanced technologies to optimize the design of a $\mathrm{CO} 2$ project for the South Cowden Unit (SCU) located in Ector County, Texas. The $\mathrm{SCU}$ is a mature, relatively small, shallow shelf carbonate unit nearing waterflood depletion. The second objective is to demonstrate the performance and economic viability of the project in the field. This report includes work on the reservoir characterization and project design objective and the demonstration project objective.

\section{SUMMARY OF TECHNICAL PROGRESS}

\section{PHASE I}

\section{Evaluation of Surfactants Adsorption}

Previous adsorption studies with South Cowden Unit cores performed in the laboratory indicated a strong dependency of surfactant adsorption on core porosity. In an effort to rank the best two surfactants (Phodapex CD-128 and Chaser CD-1045) for the South Cowden Unit CO2-foam applicatiaons, Baker Dolomite cores which are quite uniform were selected for these studies. Ten adsorption tests were performed in Baker Dolomite cores in the absence of crude oil. Each core was flooded with 1000,2000 or $3000 \mathrm{ppm}$ surfactant. A total of $30 \mathrm{mg}$ surfactant was injected in each core test followed by sufficient amount of synthetic South Cowden Unit brine. The core effluents were monitored with a Waters Model 410 Differential Refractometer. The surfactant concentration in the effluents was also determined by measuring the Total Organic Carbon (TOC). Average surfactant adsorption for CD-1045 measured at $10 \mathrm{pv}$ by Refractive Index (RI) and TOC are 419 and $425 \mathrm{lbs} / \mathrm{acre}-\mathrm{ft}$, respectively. Average surfactant adsorption for Phodapex CD-128 are $81 \mathrm{lbs} / \mathrm{acre}-\mathrm{ft}$ (RI) and $93 \mathrm{lbs} / \mathrm{acre}-\mathrm{ft}$ (TOC).

\section{Technology Transfer}

A poster session entitled "Reservoir Characterization of an Upper Permian Platform Carbonate in Preparation for a Horizontal-Well CO2 Flood, South Cowden Unit, West Texas" was presented by C.D. Caldwell at the Oklahoma Geological Society / U.S. Dept. Of Energy Symposium, "Platform Carbonates in the Southem Midcontinent", Oklahoma City, OK, March 26-27, 1996. A number of core samples were included in the exhibit. Copies of the abstract and the symposium schedule are attached. (Attachment I)

The Society of Petroleum Engineers Permian Basin Oil \& Gas Recovery Conference held March 2729, 1996 in Midland, TX included a poster session entitled "Construction of a 3-D Geologic Reservoir Description from Core and Well Log Data, South Cowden Field CO2 Project". A technical paper, SPE 35226, "Use of Production and Well Test Data with Predictive History 
Matching to Improve Reservoir Characterization for $\mathrm{CO} 2$ Flooding at the South Cowden Unit" by K. J. Harpole, M.G. Gerard, S.C. Snow, and C.D. Caldwell was also presented. This paper presented the approach used in the South Cowden project to improve the delineation of the porosity and permeability distribution in the reservoir by integrating production performance data with 3-D geological modeling and predictive history matching techniques. A copy of the session schedule is attached, along with a copy of the technical paper. (Attachment II) Reprint remould for

$$
\text { separte cycling. }
$$

\section{PHASE II}

\section{Reservoir Simulation}

The South Cowden full-field simulation model was expanded and updated to accomodate revised reservoir desciption information resulting from: (a) inclusion of data from five additional wells drilled in the project area, and (b) improvements in delineating the porosity and permeability distribution in the project area by integrating production performance data with 3-D geological modeling. The field performance history match was updated using the revised model. This resulted in significant improvements in individual well performance matches.

The revised simulation model was used to update $\mathrm{CO} 2$ flood performance forecasts and to optimize final horizontal well locations, orientation, and completion strategy. Based on the revised forecasts, the western horizontal well (SCU $7 \mathrm{Cl1H}$ ) was reoriented to conform to local reservoir quality trends. The simulation model forecasts indicate that this should result in more rapid production response to $\mathrm{CO} 2$ injection. The revised project performance forecasts were also used to aid in final design of surface facilities and to finalize well conversion and workover strategies prior to implementation of $\mathrm{CO} 2$ injection.

\section{Well Drilling}

The drilling and completion plans for the two horizontal injectors were completed after the final well locations were determined. The first horizontal well, SCU 6C25H, was spudded on March 17, 1996. Land purchase for the project area was completed in January, 1996. Surface injection facility construction was begun in February, 1996.

\section{Petrographic Study of Core from SCU 6-24}

Burrow mottled dolopackstones composing the SCU reservoir interval are composed of gray, relatively low-porosity and low-permeability dolowackestones/dolopackstones and tan, oil-stained, more porous and permeable dolopackstones/dolograinstones. Tan dolomite areas are burrows. Interburrow areas are gray lower porosity dolomite. The relative amounts of gray and tan dolomites composing the SCU reservoir interval markedly affect the reservoir porosity and permeability. A clear mylar sheet with a one-inch-square grid pattern was used to determine the relative amounts of 
gray and tan dolomites composing the reservoir interval in the SCU 6-24 core. These amounts, determined for each one-foot interval of the Grayburg reservoir, will be compared with gray/tan percentages similarly determined for the SCU 8-19, 7-10, 6-23, and 8-11 cores.

Reservoir porosity is also a function of anhydrite content. Thin section study of burrow mottled dolopackstones from the SCU 8-19, 7-10, 6-23, and 8-11 and the Moss Unit 16-14 shows that as anhydrite content increases reservoir porosity decreases. Thin section study of reservoir dolomites from the SCU 6-24 confirms these findings. Average anhydrite content of tan dolomites, determined from thin sections; and average porosities, determined from core analysis, are given below:

\section{WELL}

SCU 8-19

SCU 6-23

SCU 7-10

SCU 8-11

Moss 16-14
AVER. POROSITY

$24 \%$

$21 \%$

$21 \%$

$14.5 \%$

$6 \%$
AVER. ANHYDRITE
$1 \%$
$1 \%$
$5 \%$
$11.5 \%$
$15.5 \%$

Anhydrite content in the lower part of the reservoir interval in the SCU 6-24 (Zone E below 4675', $\log$ depth) averages less than $1 \%$ anhydrite. Porosity estimated from thin section for this interval is approximately $12 \%$. Zones $E$ and $F$ above $4675^{\prime}$ average $19 \%$ anhydrite and $4.5 \%$ porosity as determined from thin section (porosities estimated from thin section are typically lower than those determined by core analysis).

Tan dolomite areas have varying permeabilities related to pore size. Tan dolomites with similar porosities may have markedly different permeabilities. The average porosity of tan dolomites from SCU $6-23$ and $7-10$ is $21 \%$, but the average permeabilities are $90 \mathrm{md}$ and $10 \mathrm{md}$, respectively. Tan dolomites from SCU 7-10 have markedly smaller pores and finer dolomite crystal size than tan dolomites from SCU 6-23. Tan dolomite samples from SCU 6-24 vary markedly in crystal size and consequent pore size, resembling samples from both SCU 7-10 and 6-23. 
Workshop Announcemont and Program

PLATFORM CARBONATES IN THE SOUTHERN MIDCONTINENT

March 28-27, 1988

Research and Studles Deallng Whth:

Platform-Carbonato Deposttion,

Dlagenosle, Rosorvolr Charactorization, Exploration, and Potroloum Production; Arbuckle, Viola, Hunton, Misslesipplan, Pennoyivanlan, and Pormian Carbonates To be hold at:

Clarion Hotel/Comfort Inn Conference Center Oklahoma City, Oklahoma

Co-Sponsored by:

Oktahoma Goological Survoy and Bartionville Project Office, U.S. Dept. of Enorgy

\section{Nonday, Maroh 25}

REGISTRATION AND INFORMATION

Main Lobby of Clarion Hotol 5:00-8:00 p.m.

EARLY-BIRD PARTY

Gold Crown Room, Clarion Hotol 6:00-8:00 p.m.

\begin{tabular}{|c|}
\hline $\begin{array}{l}\text { Twoeday, March } 26 \\
\text { REcistrattoN } 7: 30 \text { a.m. }-5: 00 \text { p.m. }\end{array}$ \\
\hline $\begin{array}{l}\text { TECHNCAL PROQRAM } \\
\text { Gold Crown Room, Clarion Hotel } \\
\text { 8:30 a.m. }-4: 30 \text { p.m. }\end{array}$ \\
\hline $\begin{array}{l}\text { POSTER SESSION } \\
\text { Gold Crown Room, Clarion Hotel } \\
4: 30-6: 30 \text { p.m. }\end{array}$ \\
\hline $\begin{array}{l}\text { BANQUET } \\
\text { Congress Room, Clarion Hotol, 7:00 p.m. } \\
\text { (Cocktails at 6:00 p.m.) }\end{array}$ \\
\hline $\begin{array}{l}\text { Wedneady, Maroh } 27 \\
\text { REGISTRATION 7:30 a.m.-3:00 p.m. }\end{array}$ \\
\hline $\begin{array}{l}\text { TECHMCAL PROGRAm } \\
\text { Gold Crown Room, Clarion Hotol } \\
\text { 8:00 a.m. }-3: 30 \text { p.m. }\end{array}$ \\
\hline
\end{tabular}

Univorsity of Arkansas, and Patrick $K$ SUTHERLAND, University of Oklahoma

1:30 Characteristlce of Cycllcal, Mbxed Carbonatel Siliciclestle Reservolrs: Early Permian Chase Group, Northern Oklahoma, by James R. CHAPLIN, Oklahoma Geological Survey

2:00 Improved Dolomtte-Reenrvalr Charncterizetion Through integrated Log and Core Analysls: Example from Wolch Field, Daweon County, Texas, by Grogory D. HINTERLONG, OXY USA, Inc., Midland

2:30 Solemic Predictlon of Reservoir Properties in - San Andres Carbonatio Reservolr, Wolch Fleld, Dawson County, Toxas, by Georgo P. WATTS and Gregory D. HINTERLONG, OXY USA, Inc., Midland

3:00 Dlecueston of afternoon papers

3:30 End of workshop

\section{Poster Session \\ Tuesday, March 26, (4:30-6:30 p.m.) \\ Cold Crown Room; Clarlon Hoted}

Carbontub Devetopment and Powntal Producttrity in the Southern Fort Worth Basln, Texas, by Doborah $K$. SACREY, Sacroy Goologled Services, Houston, and A. H. WADSWORTH, Indopendent Geologlst, Houston

Production and Recorvolr Charactirittice of Selected Hunton Fiolds In the Anadarko Basin, by Paul W. SMITH, Wattor J. HENDRICKSON, and Cals M. mLLuars, Dwights Enworgydata, Oklatioma Clty

Potrofoum Production from Platform Carbonative of Oklahoma, by G. Cartyle HIHSHAW, Goo Information Sye. toms, Norman, Konneth S. JOHNSON, Oklahoma Coologled Survoy, and Robert A. NORTHCUT, Independemt Geologint, Oktatioma Clty

Integrabed Rosurvolr Manugement and Roservoly Charecterization of the North Roberteon Unth, aelnee County, Texas, by P. K. PANDE and James E. KAMIS, Fina, Mhotiend, Plichurd VESSEL, D. K. Davles \& Alsociatos, Houston, Mile CLARK, Fina, Houston, Mohen KELKAR, University of Tulea, and $L$ DOUBLET and Tom BLAsmaANE, TOXas A\&M Univeralty

Mitcrobtal Reservots Characturization of the Hobart Field, Klown County, Otdihoms, by Dantol HITZaMaN, James D. RUCKER, and Brooks A. ROUNTHEE, GMT, Ino, Ochointa, OK

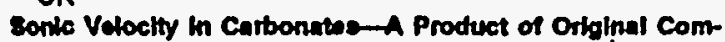
positton and Post-Depostitonal Poroulty Evotition, by provito S. ANSELMETrI and Gregor P. EDERU, Untiverelity of Plavio

Miom

Four Hundrod Feet of core trom the Cambrtan stomal

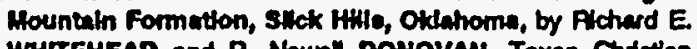
WHITEHEAD and R. Nown DONOVAH, Toxas Chisten Univestly

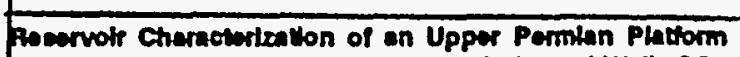
Carbonatio in Proparntion for a Horlzontan-Well $\mathrm{CO}_{2}$ Flood, South Cowden Unit, Weat Twons, by Crals $\mathrm{D}^{2}$. CALOWELL, Phillips Potoloum Co., Barthosills, OK, and Matt OERARD and Susan SNOW, Pthlips Potroleum $C_{0}$. Qdossen $7 X$

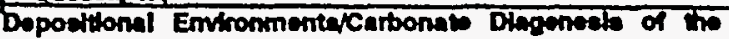
Councll Crow Group, Hugoton Emberment, sourthwe Keneas, by Nicholas J. PIERACACOS, Bnylor Univereity

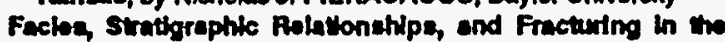
Wapanucke and spleo, by Darroll MAULOW, Independert Qoolooile, Cyydo, TX

The Boundary Batweon the fort sill and stgnal Mountaln Formattons in the Lower Arbuckts Croup, sinck Hilla: Candidato for a Crand Cycle Bound ary, by Randy HOSEY, Cross Timbers on Co., Fort Worth, and R. Nownil DONOVAN, Toxas Chrietien Univeralty

Lthofactes Diectibution and Recervolf Howrogenolty within Penneytumitan Btotherme, Western Orogrands Bacln, Now Pennoytuantan Btohorme, Wastern Orogrands Bacln, Now and Kathoins QHLES, Now Moxico Stato Unlvoraity

Unton Valloy Umeetone Bank (Morrowan, Penneytunnien), Enatom Oldatioma, by Jamos R. DERBY and James O'BRuEN, Independent Goologists, Tuliea

Deposttional and Diagenotle History of Imecicalpplen Chat Recervile, Northem Otthioma, by Surane M ROQEAs, Jamos $M$. FORQOTSON, $k_{\text {. }}$ and Thomms $A$. DEWEAS, Univoraty of Otdatioma

Lthoutratloraphy and Blowtratigraptry of a Core from the Vhole and stmpeon Groups in Koener "19-B Woll, Croek County, Otdatiomm, by Jamos R. DERBY and dames O'BRIEN, Indepondont Coologiluts, Tutien, and John E. REPETSKa, U.S. Goological Survoy, Roston, VA

stratigrapiny of the Roubldoux Formatton of Mlenourl and Correlattwo Units in the southem Mldcontinent, by John E. REPETSK, U.S, Geoloolal SUrvey, Auston, VA Jimee D. LOCH, Contwl Missouri Stato Univeralty, and Raymond $L$ ETHINGTON and Rumell I. DREsBách, Untverety of Mloscunt - Columbla

Pegloral Corretuttone of the Springer and Chower Groupe Within the Otdehomn Portion of the Aradurto Bacin and Bhelf Demonetrating the Facles Changes Within the Sportnger Which thave Roentind in Sprtnger Bolm Mle. identiod

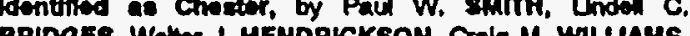
BAlDats, Whethor, and Roneld J. WOODS, Dwight's Enorgydata, OKC City

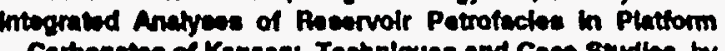
Carbonaties of Kananes: Technlques and Caces sudies, by Jahn H. DOVETOH, W. Lymn WATMEY, and Witerd J. GUY, Kensas Geological Survoy

Prollminary Cyelke Siratigraphy of the Upper Arbuctite

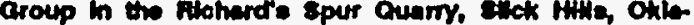

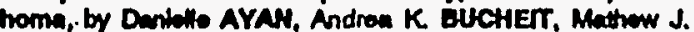
KULOW, and A. Nown DONOVAH, Texas Chrietian Unty.

Outcrop-baced Sequencos Strattgrephle Anetyate of the Admire and Counch arovs Groups of Kancese and Orte. home, by Darwin R. BOARDMAN II, Otdahoma Stato Untr. 


\section{RESERVOIR CHARACTERIZATION OF AN UPPER PERMIAN PLATFORM CARBONATE IN PREPARATION FOR A HORIZONTAL-WELL CO2 FLOOD, SOUTH COWDEN UNIT, WEST TEXAS}

Craig D. Caldwell, Matt G. Gerard, Susan G. Snow, and Ken J. Harpole, Phillips Petroleum Co.

Since initial development in the late 1940s, South Cowden Unit (SCU), located on the eastern margin of the Central Basin Platform, has produced 35 million barrels of oil from the Upper Permian Grayburg Formation. Grayburg strata at SCU drapes over a Lower San Andres thick resulting in an unfaulted anticlinal structure. Under waterflood since 1965, SCU is approaching the economic limit of waterflood operation, and a $\mathrm{CO} 2$ flood employing horizontal injection wells has been proposed. In preparation for the proposed flood a detailed geologic description of the reservoir interval was prepared for integration into a reservoir simulation model.

The reservoir interval at SCU is approximately $150 \mathrm{ft}$. thick and is composed mainly of burrowmottled dolopackstone. These dolomites are characterized by a distinctive gray/tan mottling reflecting variations in oil staining. Tan oil-stained areas, interpreted to be carbonate-sand-filled burrows, are typically 2 to $8 \mathrm{~cm}$ in width, up to a few tens of centimeters in length, and vertically oriented. Tan areas are dolograinstones, dolopackstones, and washed dolopackstones. Porosity in these areas is intergranular, moldic, and intercrystalline and ranges typically from 10 to $32 \%$. Permeability varies generally from 2 to $400 \mathrm{md}$. Gray interburrow areas lacking oil staining are dolopackstones and dolowackestones with 2 to $9 \%$ moldic and intercrystalline porosity and 0.002 to $2 \mathrm{md}$ permeability. The relative amounts of $\tan$ and gray dolomite determined by the degree of bioturbation can profoundly affect reservoir porosity and permeability.

Reservoir porosity and permeability are also a function of anhydrite content. An inverse relationship exists between porosity and permeability and the amount of poikilotopic anhydrite cement in the tan dolomite areas. Limited data suggests the decrease in porosity in the northwestern (paleolandward) part of SCU is related, at least in part, in an increase in anhydrite content.

Reservoir permeability is also affected by pore size as related to crystal size and depositional texture of the tan dolomite areas. Finely to medium-crystalline tan dolomites typically have markedly larger pores and significantly greater permeabilities than very finely to finely crystalline tan dolomites with similar porosities. Very finely to finely crystalline tan dolomite areas reflect muddier burrow-filling sediments. This porosity/permeability relationship necessitates more than one porosity/permeability transform to characterize rocks of the SCU reservoir interval.

The vertically oriented character of porous and permeable tan dolomite areas characterizing rocks of the reservoir interval provides a favorable condition for the application of a $\mathrm{CO} 2$ flood which employs horizontal injection wells. The vertical movement of fluids and gases through the reservoir interval may be partially restricted, however, by two, laterally continuous, relatively lowpermeability sandy dolopackstone layers. These relatively thin sandy dolomites are used to establish a reservoir zonation. 

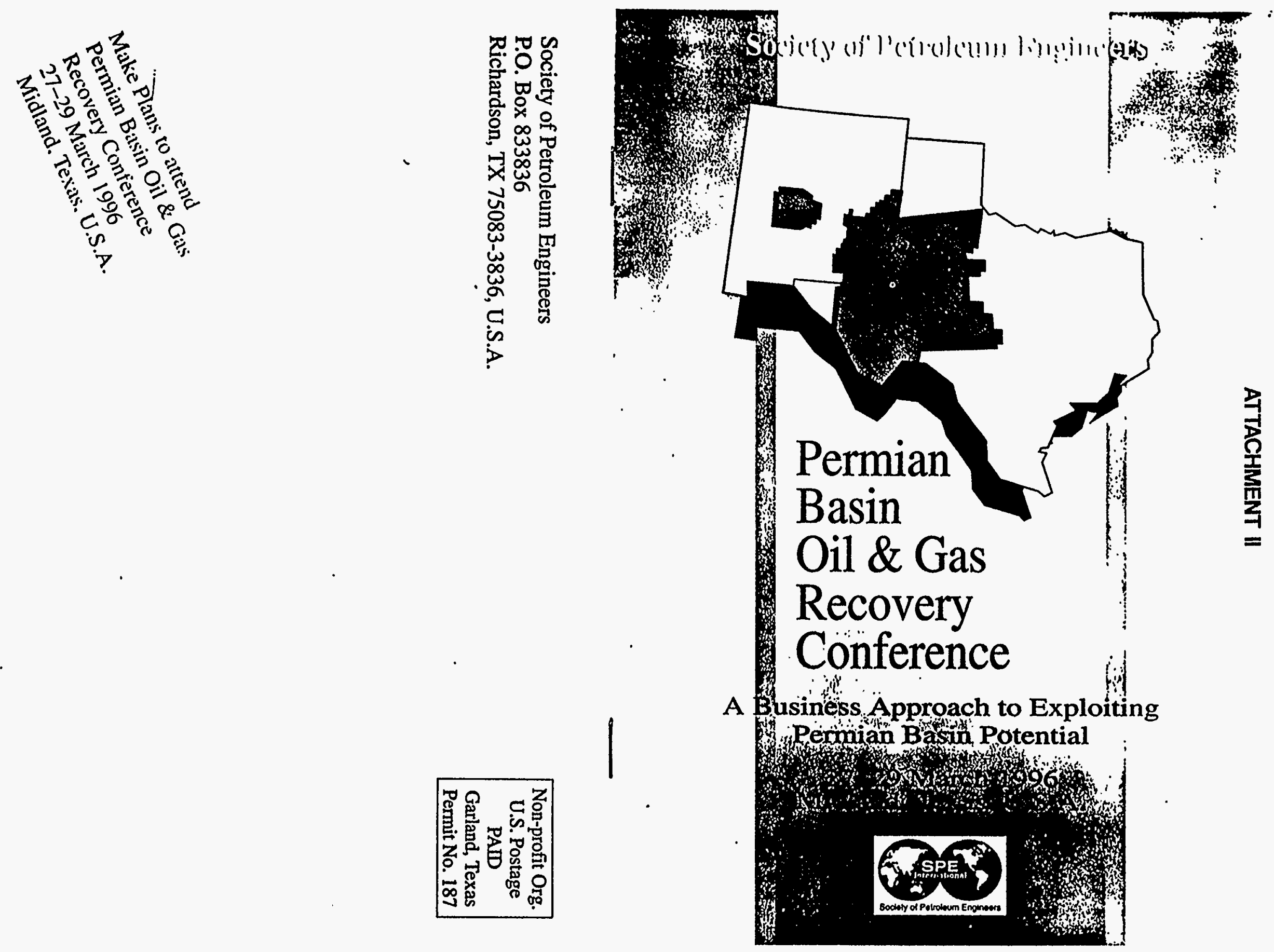
35201 Puind-Neutron Capeure Lozelng in Reservolr Mnnmetinent: Three Permlan Basin Examples - F.M. Haynes, Exxon Co. USA

35202 Areal Distribution of Remaining Ofl Saturation In a Mature West Texas Waterhood-A Case History - A.K. Sharma and A. Kumar, Mobil E\&P U.S. Ine

35203 A New Approach to Lange-Scale Infill Evaluattons Applled to the Ozona Canyon Gas Fitelds $\bullet$ G.W. Voneiff, S.A. Holditch and Asjocs. Inc.; and C.L. Cipolla, Union Pacific Resources Co.

35204 Reserves and Performance of Canyon Sand Gas Wells, 1970-1994 • G.S. Swindell, Gary S. Swindell and Assocs.

35205 Eveluation of Injectlon Well Performance Using Type Curves • S. Prachumchon and T.A. Blasingame, Texas A\&M U.

Alternate

30202 Predictlng Production UsIng a Neural Network (Artifnclal Intelligence Beats Human Intelligence) • R.J. Boomer, Texaco E\&P Inc.

Thursday, 28 March 1996 2:00-5:00 p.m.

Horizontal Well Applications - Midland Center, Room 2

Session Chairmen: Siephen N. Guillot, Texaco E\&P Inc.

SPE Samuel L. Pickell, Mobil E\&P Services Ine.

35207 Status of Horizontal Drilling In the Permian Basin • C.R. Vanorsdale, T. Scoll Hickman and Assocs. Inc.; and R. Vogel, Vogel Engineering Inc.

35208 Stmulation Studles of Waterfood Performance With Hortzontal Wells $-\mathrm{H}$. Ferreira, Petresim Integrated Technologies Inc.; and D.D. Mamora and R.A. Starzman, Texas A\&M U.

35209 Waternood Infill Well Pattern Strategles for Horizontal and Mullilateral Wells C.A. Ehlig-Economides, Anadril

35210 Fleid Applieation of Multilateral Horizontal Wells in a 5.Spot WalerRood, S.E. Utah e S.D. Hall, Texaco E\&P Inc.

35211 Evaluation of Horizontal Wells With Tranavene Hydraulic Fractures in a Layered Mullt-Phuse Reacrvoir • R.A. Watlenbarger and E.A. Elrafie, Texas A\&M U.

33212 An Endneer's Guide lo Legal and Regulatory lasues for Horizontal Wella in Texas o J.S. Judah, McElroy and Sullivan LLP

Alternate

35213 Interactlons of the Horlzontal Wellbore Hydraulles and Formatlon Damage • F. Civan, U of Oklahume

Thursday, 28 March $1996 \cdot 2: 00-5: 00$ p.m.

Production Operations - Midland Center, Room 5

Session Chairmen: Victoria B. Jackson. Unocal SPE Richard S. Prentice, Ref-Chem

30680 Tubing Flowrate Controller: Maximlze Gas Well Production From Sturt to Fintsh W.O. Elmer, Conoco Inc.

35214 Euler Loads and Measured Sucker RodSucker Bar Buckling • S.W. Long and D.W. Bennett, Flexbar Inc.
30636 Automation In Cycikal Rate Primary Rewervolr Sigulficantly Reduces Beam Pump Fallures • C.P. Findlay II and R.B. Herting. Conoco Ine.: and J.L.S. Pike, Della.X Corp.

35216 Improved Water Flood Operation in the Permlen Basin Through Mkrobial Culture Trentment •D.R. Schneider, Micro-Bac Intl.: T. Ratliff, Bio-Tech Inc.: and B.C. Hoskins, Micro-Bac Intl.

35217 Revlew of Downhold Dynamometer Testing - R.L.Soza, Exxon Co. USA

35218 ALWORKS-An Artinclil Lin Surveillance Tool • G.L. Burleson, Exxun Co. USA: and 3.D. Redden, Exxon Production Research Co.

Alternate

35219 Water and Gus Coning in the OUll Reservolrs With Steady State and Translent Flow (Part I: Vertical Wells) - F. Azamejud, W.S. Torike, and S.M. Farouy Ali. U. of Alberta

Thursday, 28 Marcli 14yo • y: 0 U u.m. $-5: 00$ p.m.

Poster Session II/Core Workshop - Midland Center, Room 3

Session Chairman: Michael J. Rauer, Ref-Chem

27657 Application of Integrated Reservoir Management and Reservoir Characterization to Optimize Inflll Driling • P.K. Pande and M.B. Clark, Fina Oil \& Chemical Co.; T.A. Blasingame. Texas A\&M U.; M. Kelkar, U. Of Tulsa; R.K. Vessell, David K. Davie. and Assces.s. Inc.; and P.E. Hunt, Mobil Corp.

35221 Construction of 3D Geologle Reservolr Description From Core and Well Log Data, South Cowden Field CO, Project • C. Caldwell, M.G. Gerard, and M. Naguly. Phillips Petroleum C.

35225 Applicatlon of Anslytical Techniques to Evaluate the lieterogenelties of the Upper Spraberry Formatlon (Permian) and Its Innuence on the Quallty of the Reservolr • C.S. Saleta, A.K. Banik, M.E. Cather, and D.S. Schechter, New Mexico Petroleum Recuvery Research Center

Friday, 29 March 1996 • 9:00 a.m.-12:00 noon

Department of Energy Projects - Midland Hilton Civic Room Session Chuirman: Leun M. Roc, Chevron USA Inc.

SPE

35223 CO, Huff-n.Puff: InIttas Results From a Waterflooded SSC Reservolr • C.S. Wehner, Texaco E\&P Inc.; and J. Prieditis, Texaco E\&P Technolugy Div.

35224 Charactertzation of the Naturall -Fractured Spraberry Trend Shaly Sands Based on Core and Log Data - A.K. Banik and D.S. Schechter, New Mexico Petroleum Recovery Research Center

35469 Reservoir Characterizatton and CO, Pilot Design in the Naturally-Fractured Spraberry Trend Area •D.S. Schechter, New Mexico Petroleum Recovery Research Center

35226 Use of Productlon and Well Teat Data With Predletlve Hlstory Matching 10 Improve Reservolr Characterization for CO, Flooding al the South Cowden Unit - K.J. Hurpule, M.G. Gerard and S.C. Snow, Phillips Petroleum Co.

kepriat semorvex for separate cycling. G 